\title{
Dental Depigmentation and Lowered Content of Iron in the Incisor Teeth of Rats Deficient in Vitamin A or $\mathbf{E}$
}

\author{
BY T. MOORE \\ Dunn Nutritional Laboratory, \\ University of Cambridge and Medical Research Council \\ AND R. L. MITCHELL \\ The Macaulay Institute for Soil Research, Aberdeen
}

(Received 2 November 1954)

It has long been known that the brown enamel layer on the anterior surfaces of the rat's incisor teeth loses its colour as the result of any one of several dietary defects. Thus Wolbach \& Howe (1925, 1933) described the bleaching as an effect of vitamin A deficiency, and other workers (Smith \& Lantz, I933; Schour, Smith \& Hoffman, r938; Schour, Hoffman \& Smith, I94I; Irving \& Richards, I939; Mellanby, 1939) confirmed their observation. McCollum, Simmonds, Becker \& Bunting (1925) reported bleaching in fluorine poisoning, and Duckworth (1942) has observed similar effects in deficiency of magnesium. The production of depigmentation by deficiency of vitamin $A$ or vitamin $E$, and its cure by whichever vitamin was missing, was described by Moore (1943).

The presence of iron in the brown enamel, already noticed by Lowater \& Murray (1937), was independently observed by Dam \& Granados (1945). The enamel of normal rats was stained blue by potassium ferricyanide, but that of rats deficient in vitamin $\mathrm{E}$ remained unstained. Dam, Granados \& Maltesen (1950) have given values for the mineral content of normal and bleached teeth. Deficiency of vitamin E caused a pronounced reduction in the iron content of the enamel and dentin, accompanied by increases in the manganese content.

The main purpose of the present paper is to give evidence confirming the conclusion that the percentage of iron in bleached enamel is much reduced. The amounts of iron found in normal teeth were, however, much lower than those reported by Dam and his colleagues. Moreover we have been unable to confirm the increase of manganese in the dentin of deficient animals.

In the course of the work we have compared the effects of deficiencies of vitamins $A$ and $E$ in decreasing the iron content of the enamel. We have had opportunities also to compare the liability to depigmentation and the iron content of the teeth of male and female rats, of albinos and piebalds and of rats of different ages receiving the same diet.

\section{EXPERIMENTAL AND RESULTS}

Diets. The basal diet (no. r) used in most of our experiments had the following percentage composition: casein (vitamin-free) 25 , sucrose 50 , lard ro, dried yeast ro and salt mixture 5 . Vitamin D was supplied as $\mathrm{I} \cdot 5 \mu \mathrm{g}$ ergocalciferol and vitamin $\mathrm{K}$ as 
50 $\mu \mathrm{g}$ 2-methyl-r:4-naphthoquinone per rat weekly, both dissolved in a drop of arachis oil. For producing vitamin A deficiency in a partial and chronic form, which was necessary to allow time for the teeth to lose their pigment, the rats were given small amounts of vitamin A acetate, usually 28 i.u. weekly. In addition they were given I, 2 or $3 \mathrm{mg} \mathrm{DL}-\alpha$-tocopheryl acetate weekly in different experiments. All these amounts were adequate to prevent vitamin $\mathrm{E}$ deficiency, and the allowances of more than $\mathrm{I} \mathrm{mg}$ weekly in some experiments were only given as a margin of safety. For producing vitamin $\mathrm{E}$ deficiency tocopherol was withheld and the animals were given Iooo i.u. of vitamin A acetate weekly. Positive control animals received rooo i.u. of vitamin $A$ and tocopherol.

In a few experiments an alternative diet (no. 2) was used for producing vitamin A deficiency. Its composition was: casein (vitamin-free) 20, sucrose 60, arachis oil $\mathrm{1}_{5}$, dried yeast 10 and salt mixture 5 parts. Vitamins $\mathrm{D}, \mathrm{K}, \mathrm{E}$ and small amounts of vitamin A were supplied as with diet no. I. The second diet was introduced for reason of convenience, and not with a view to comparing its effects on the teeth.

The salt mixture contained $3.8 \mathrm{I} \%$ iron citrate and $0.022 \%$ manganese sulphate.

Method of analysing the teeth. After the colour of the teeth had been recorded the upper incisors, which are normally a deeper brown than the lower, were dissected out to the roots and weighed. They were then held in a platinum wire and heated for some minutes in a Bunsen flame. As reported by Dam et al. (1950), the heating caused the enamel to become detached from the dentin. The ash from both fractions was then heated for several hours in platinum crucibles. Little further loss of weight, however, was found after the first ashing.

The analyses for iron and manganese were made by the arc spectrographic method described by Farmer (1950) for plant ash. The ash from dentin or from enamel was diluted with an equal quantity of the base from which the standards were prepared, in order to minimize errors due to matrix differences. One part of this mixture was then mixed with one part of $\mathrm{K}_{2} \mathrm{SO}_{4}$ and two parts of carbon powder containing the internal standard, chromium, before being filled into carbon electrodes, which were used exactly as detailed by Farmer.

\section{Dental depigmentation in different strains of rat deprived of vitamin $E$}

The investigation by one of us into the relative liability of albino and piebald rats to dental depigmentation has already been briefly reported elsewhere (Moore, 1950). In that work a group of twenty weanling female albino rats of Wistar ancestry was restricted to the basal diet no. I, supplemented with adequate doses of vitamin $A$ but with no vitamin $E$. The same diet and supplement were given also to a group of fifty similar piebald rats, of which the strain has been maintained for some 25 years in the Dunn Nutritional Laboratory from stock originally supplied by Dr Gladys Hartwell.

The colour of each upper incisor was assessed by a simplified system, two marks being given for a brown tooth, one for a mottled or faintly brown tooth and none for a white tooth. The average markings for the groups over a period of 4 months are shown in Fig. I. It will be seen that both strains had white teeth on weaning. After the first 20 days of the experiment, when the rats were about 7 weeks old, the teeth 
in each group had become brown. From that point, however, the teeth of the albinos began to bleach, so that almost all were completely white after another 40 days. In the piebalds the teeth remained brown, with few exceptions even after 9 months.

A second experiment gave substantially the same result. In the albinos, on this occasion, depigmentation usually occurred after Io weeks, whereas only a few of the piebald animals had slight mottling of the brown layer after ${ }_{5}$ weeks. Although these findings might suggest that the albino is in general more sensitive than the piebald to the effects of vitamin E deficiency, we have obtained no evidence that the difference extends beyond dental depigmentation. It will be clear, from experiments to be described below, that the teeth of piebald rats are not immune to depigmentation from causes other than vitamin E deficiency. Thus their teeth readily lose their colour in deficiency of vitamin A. Prolonged deficiency of vitamin $E$ will cause depigmentation

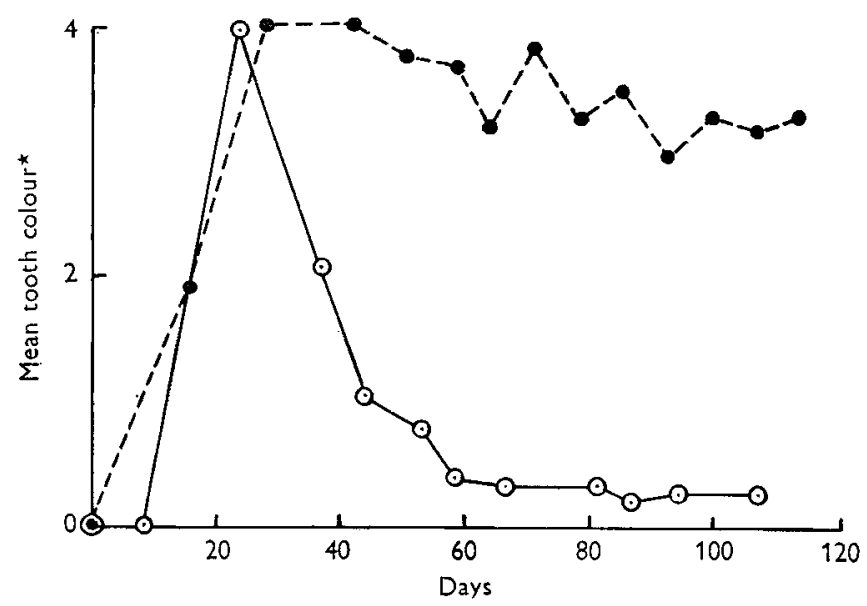

Fig. I. Comparison of the rates of dental depigmentation in albino and piebald rats deficient in vitamin $\mathrm{E}$. - , albino; --.-, piebald.

* See p. 175 .

in piebalds also when it is combined with deficiency of protein; in other experiments almost complete bleaching of the teeth was seen in piebalds subjected for 4 months to a deficiency of vitamin $\mathrm{E}$ and for a further 4 months to deficiency of protein as well.

An attempt to accelerate the appearance of dental depigmentation by the removal of the iron component from the salt mixture of weanling rats, restricted to a diet deficient in vitamin $\mathrm{E}$, was unsuccessful in both albinos and piebalds.

The delay in the appearance of dental depigmentation after dietary deprivation. The fact that the incisor teeth of the rat are continuously growing must not be overlooked in studies of depigmentation. As already pointed out (Moore, 1948-9), the teeth in the living animal may appear normal during dietary deprivation, yet may become bleached when the deficiency is remedied. Presumably during deficiency injuries are sustained by the parts of the teeth in process of formation under the gingivae. When the animal is cured the injured parts emerge and give a first impression that restoration of the missing factor has caused damage to the teeth. For example a piebald rat was placed as a weanling, weight $49 \mathrm{~g}$, on a diet (no. 2) deficient in vitamin A. After 18 days the 
incisors became brown and were still brown when growth was checked, with the body-weight at $\mathrm{I} 30 \mathrm{~g}$, after $5^{6}$ days. Dosing with 8 i.u. carotene daily was then begun, with the result that after another 42 days, when the weight had increased to $160 \mathrm{~g}$, the teeth had become completely white. Continuation of dosing for a further 24 days, however, restored the brown colour to the teeth. It seems probable that the first 6 weeks or more of dosing had the effect of exposing the damage sustained during the previous 8 weeks of deficiency.

Table I. Preliminary experiment. Iron and manganese content of the enamel and dentin from the depigmented and normal upper incisor teeth of rats deprived of vitamin $A$ or fed on a stock diet

\begin{tabular}{|c|c|c|c|c|c|c|c|}
\hline \multirow[b]{3}{*}{ Diet } & \multirow{3}{*}{$\begin{array}{c}\text { Mean } \\
\text { weight } \\
\text { of pairs } \\
\text { of fresh } \\
\text { teeth } \\
\text { (mg) }\end{array}$} & \multicolumn{6}{|c|}{ Mean composition of } \\
\hline & & \multicolumn{3}{|c|}{ Dentin } & \multicolumn{3}{|c|}{ Enamel } \\
\hline & & $\begin{array}{c}\text { Ash } \\
(\mathrm{mg})\end{array}$ & $\underset{(\%)}{\mathrm{Mn}}$ & $\begin{array}{c}\mathrm{Fe} \\
(\%)\end{array}$ & $\begin{array}{c}\text { Ash } \\
(\mathrm{mg})\end{array}$ & $\begin{array}{l}\mathrm{Mn} \\
(\%)\end{array}$ & $\begin{array}{c}\mathrm{Fe} \\
(\%)\end{array}$ \\
\hline ock, normal & $218 \cdot 4$ & $100 \% 4$ & $<0.006$ & $<0.02$ & $28 \cdot 3$ & $<0.006$ & 0.23 \\
\hline $\operatorname{tamin} A$-defici & $161 \cdot 3$ & $81 \cdot 5$ & $<0.006$ & 0.03 & 23.7 & $<0.006$ & 0.08 \\
\hline
\end{tabular}

Preliminary results of analysis for iron and manganese. In the preliminary experiments the iron and manganese contents of normal brown teeth, obtained from three adult piebald male rats reared on a liberal mixed diet, were compared with those of depigmented teeth obtained from three similar animals that had received an experimental diet. The animals, for purposes irrelevant to the present communication, had been kept for 193 days on diet no. 2, with supplements of 4 i.u. vitamin A daily after the first 35 days. No vitamin $\mathrm{E}$ was given beyond any contributed by the $15 \%$ of arachis oil in the diet. Although the teeth seemed completely white over a long period, light brown mottlings were present at the time of killing. The results obtained are shown in Table 1 .

It will be seen that the enamel of the normal teeth contained $0.23 \%$ of iron, compared with only $0.08 \%$ in the depigmented teeth. In the dentin of the normal teeth the percentage of iron was too low for analysis, but a trace, just above the sensitivity level of the test, was found in the dentin of the depigmented teeth. The quantity of manganese in every ash was too low for determination.

Main experiments on content of iron and manganese. In the main experiments the incisors of groups of rats deprived of either vitamin A or vitamin $\mathrm{E}$ for long periods were compared with those of animals similarly treated, but receiving doses of the missing vitamin. Some of the groups were reared specially to provide teeth, but teeth were collected also from groups of animals made deficient in connexion with other work. In consequence the period of restriction in different groups differed considerably. In Table 2 groups that received their diets for the same number of days have been considered directly comparable.

As in the preliminary experiments, the ash from the enamel and from the dentin was weighed and analysed for iron and manganese in all groups. In all ashes from dentin the percentage of iron was below 0.02 . In both enamel and dentin no 
manganese could be found by a method capable of detecting $0.002 \%$. Even a method capable of detecting $0.0005 \%$, applied to some specimens only, gave no evidence for the presence of manganese. In order to simplify the presentation of results, therefore, Table 2 includes values only for the iron content of the enamel ashes. To facilitate comparison the figures for certain groups have been repeated in different parts of the table.

Table 2. Iron content of the ash from enamel of the upper incisor teeth of rats given diets adequate or inadequate in vitamin $A$ or vitamin $E$

\begin{tabular}{|c|c|c|c|c|c|c|c|c|c|}
\hline \multirow[b]{2}{*}{ Nature of experiment* } & \multirow[b]{2}{*}{$\begin{array}{c}\text { Group } \\
\text { no. }\end{array}$} & \multirow[b]{2}{*}{ Strain } & \multirow[b]{2}{*}{$\begin{array}{l}\text { No. } \\
\text { of } \\
\text { rats }\end{array}$} & \multirow[b]{2}{*}{ Sex } & \multirow[b]{2}{*}{$\begin{array}{c}\text { Diet } \\
\text { no. }\end{array}$} & \multirow[b]{2}{*}{$\begin{array}{c}\text { Dura- } \\
\text { tion } \\
\text { of diet } \\
\text { (days) }\end{array}$} & \multicolumn{3}{|c|}{$\begin{array}{c}\text { Enamel of } \\
\text { upper incisor teeth }\end{array}$} \\
\hline & & & & & & & $\begin{array}{l}\text { Mean } \\
\text { weight } \\
\text { of ash } \\
\text { (mg) }\end{array}$ & Colour & $\begin{array}{c}\text { Mean } \\
\text { Fe } \\
\text { content } \\
(\%)\end{array}$ \\
\hline Deprivation of vitamin $E$ & $\begin{array}{l}2 \\
7 \\
9\end{array}$ & $\begin{array}{l}\text { Albino } \\
\text { Albino } \\
\text { Albino }\end{array}$ & $\begin{array}{l}3 \\
2 \\
3\end{array}$ & $\begin{array}{l}0 \\
0 \\
+ \\
0\end{array}$ & $\begin{array}{l}\mathbf{I} \\
\mathbf{I} \\
\mathbf{I}\end{array}$ & $\begin{array}{r}80 \\
140 \\
200\end{array}$ & $\begin{array}{l}29 \cdot 0 \\
26 \cdot 6 \\
23 \cdot 0\end{array}$ & $\begin{array}{l}\text { White } \\
\text { White } \\
\text { Mottled }\end{array}$ & $\begin{array}{r}<0.02 \\
<0.02 \\
0.04\end{array}$ \\
\hline No deprivation & $\begin{array}{r}3 \\
8 \\
10\end{array}$ & $\begin{array}{l}\text { Albino } \\
\text { Albino } \\
\text { Albino }\end{array}$ & $\begin{array}{l}3 \\
2 \\
3\end{array}$ & $\begin{array}{l}0 \\
0 \\
0 \\
0 \\
0\end{array}$ & $\begin{array}{l}\mathbf{r} \\
\mathbf{I} \\
\mathbf{I}\end{array}$ & $\begin{array}{r}80 \\
440 \\
200\end{array}$ & $\begin{array}{l}28 \cdot 7 \\
30 \cdot 1 \\
21 \cdot 2\end{array}$ & $\begin{array}{l}\text { Brown } \\
\text { Brown } \\
\text { Brown }\end{array}$ & $\begin{array}{l}0.07 \\
0.27 \\
0.24\end{array}$ \\
\hline $\begin{array}{l}\text { Partial deprivation of } \\
\text { vitamin A }\end{array}$ & $\begin{array}{l}1 \\
4 \\
6\end{array}$ & $\begin{array}{l}\text { Albino } \\
\text { Pied } \\
\text { Pied }\end{array}$ & $\begin{array}{l}3 \\
3 \\
2\end{array}$ & $\begin{array}{l}0 \\
0 \\
0 \\
0\end{array}$ & $\begin{array}{l}1 \\
1 \\
2\end{array}$ & $\begin{array}{r}80 \\
230 \\
340\end{array}$ & $\begin{array}{l}r 8 \cdot 9 \\
34 \cdot 5 \\
3 I \cdot I\end{array}$ & $\begin{array}{l}\text { Cream } \\
\text { Mottled } \\
\text { White }\end{array}$ & $\begin{array}{l}0.03 \\
0.10 \\
0.04\end{array}$ \\
\hline No deprivation & $\begin{array}{r}3 \\
5 \\
10\end{array}$ & $\begin{array}{l}\text { Albino } \\
\text { Pied } \\
\text { Albino, }\end{array}$ & $\begin{array}{l}3 \\
3 \\
3\end{array}$ & $\begin{array}{l}\hat{0} \\
0 \\
0 \\
0\end{array}$ & $\begin{array}{l}\mathbf{I} \\
\mathbf{I} \\
\mathbf{I}\end{array}$ & $\begin{array}{r}80 \\
230 \\
200\end{array}$ & $\begin{array}{l}28 \cdot 7 \\
39 \cdot 7 \\
21 \cdot 2\end{array}$ & $\begin{array}{l}\text { Brown } \\
\text { Brown } \\
\text { Brown }\end{array}$ & $\begin{array}{l}0.07 \\
0.27 \\
0.24\end{array}$ \\
\hline $\begin{array}{l}\text { No deprivation, comparison } \\
\text { of albino and piebald }\end{array}$ & $\begin{array}{r}10 \\
5\end{array}$ & $\begin{array}{l}\text { Albino } \\
\text { Pied }\end{array}$ & $\begin{array}{l}3 \\
3\end{array}$ & $\begin{array}{l}a \\
a \\
0\end{array}$ & $\begin{array}{l}1 \\
I\end{array}$ & $\begin{array}{l}200 \\
230\end{array}$ & $\begin{array}{l}21 \cdot 2 \\
39 \cdot 7\end{array}$ & $\begin{array}{l}\text { Brown } \\
\text { Brown }\end{array}$ & $\begin{array}{l}0.24 \\
0.27\end{array}$ \\
\hline $\begin{array}{l}\text { No deprivation, comparison } \\
\text { of male and female }\end{array}$ & $\begin{array}{r}10 \\
8\end{array}$ & $\begin{array}{l}\text { Albino } \\
\text { Albino }\end{array}$ & $\begin{array}{l}3 \\
2\end{array}$ & $\begin{array}{l}0 \\
\text { o } \\
\dot{9}\end{array}$ & $\begin{array}{l}\mathbf{I} \\
\mathbf{I}\end{array}$ & $\begin{array}{l}200 \\
140\end{array}$ & $\begin{array}{l}21 \cdot 2 \\
30 \cdot 2\end{array}$ & $\begin{array}{l}\text { Brown } \\
\text { Brown }\end{array}$ & $\begin{array}{l}0.24 \\
0.27\end{array}$ \\
\hline
\end{tabular}

* Vitamin E supplement: groups 8 and ro had I mg DL- $\alpha$-tocopheryl acetate per head weekly; groups 4, 5 and 6 had $2 \mathrm{mg}$, and groups I and 3 had $3 \mathrm{mg}$. Vitamin A supplement: groups $\mathrm{I}, 4$ and 6 had 28 i.u. vitamin A acetate per head weekly; all other groups had rooo i.u.

It will be seen that the ash of the brown enamel in groups 5,8 and ro contained $0.27,0.27$ and $0.24 \%$ iron, respectively. These values are all close to that of $0.23 \%$ found in the preliminary experiment for normal rats receiving a mixed diet (Table $\mathrm{r}$ ). A much lower value of $0.07 \%$, however, was found in group 3, in which also the enamel was brown. Possibly the difference arose because the animals in group 3 were much younger than in the other groups. Comparison between groups 5 and ro shows that brown enamel taken from albino and piebald rats contained about the same percentage of iron. Comparison between groups 8 and to shows values for males and females that are closely similar.

In the groups with depigmentation the iron content of the enamel ash was always much lower. Thus the ash from groups 2, 7 and 9, deficient in vitamin E, contained $<0.02,<0.02$ and $0.039 \%$, respectively. In the ash from groups I and 6 , deficient in vitamin $A$, only slightly higher percentages, 0.033 and 0.042 , were found. The higher value of $0.10 \%$ in group 4 is associated with the fact that the teeth were incompletely bleached. 
The results of our experiments confirm the finding of Dam \& Granados (1945) that the brown enamel layer of the rat's incisor teeth is rich in iron, most of which disappears when the enamel is bleached through deprivation of vitamin $\mathrm{E}$. In our experience, however, the iron content of the ash of brown enamel was only $0.07-$ $0.27 \%$, compared with the $\mathrm{r} .8 \%$ reported by Dam et al. (1950). For the iron content of the ash from depigmented enamel we were in better agreement, our own values $<0.02-0.1 \%$ agreeing with the $0.03 \%$ found by Dam and his colleagues.

The ash from dentin in our experiments contained less than $0.02 \%$ of iron, with one exception, which had $0.03 \%$. Dam et al. (1950) found $0.23 \%$ in the dentin of normal teeth and $0.04 \mathrm{r} \%$ in the dentin of depigmented teeth. Our failure to find even $0.002 \%$ of manganese in any ash may be contrasted with the Danish finding of 0.034 and $0.025 \%$ in the enamel and dentin ashes from normal teeth and 0.093 and $0.105 \%$ in the corresponding ashes from depigmented teeth.

It is possible that the quantitative differences between our results and those of Dam et al. (1950) may have been due to differences in experimental conditions. In the Danish work the rats received diets high in cod-liver oil and low in protein. Even if difference in conditions affords an explanation, the importance and specificity of the role that has been ascribed to vitamin $\mathrm{E}$ in regulating the metabolism of iron and manganese remain open to question. In our experience iron was lost from enamel that had been bleached by deficiency of either vitamin $E$ or vitamin A. Moreover, by a chemical method Murray, Glock \& Lowater (1939) found at least a slight decrease in the iron content of the teeth in fluorosis; the enamel ash of normal upper incisors contained $0.1382 \%$ of iron, compared with $0.0909 \%$ in fluorosis. It seems probable that any treatment causing depigmentation of the teeth will decrease their iron content.

The greater resistance to dental depigmentation in vitamin $\mathrm{E}$ deficiency shown by the piebald than by the albino rat recalls an early report by Telford (1946). Rats of the Long-Evans strain, originally obtained by crossing albino rats with wild grey rats, remained immune from depigmentation when deprived for long periods of vitamin $\mathrm{E}$. A difference in iron metabolism between strains of rats has been reported by Bacharach, Cuthbertson \& Thornton (1949), who found that the weanling albino rats became anaemic on a maternal diet low in iron, but that piebald weanlings did not.

The delay in appearance of dietary effects on the visible portion of the tooth recalls early work by Fish \& Harris (1934). In studying the effect of vitamin C deficiency on the teeth of the guinea-pig, they found that the regions of the teeth formed at different times were normal or abnormal according as the contemporary supply of the vitamin was adequate or defective. By changing the intake of the vitamin alternating normal and abnormal zones could be produced in the continuously growing teeth. 


\section{SUMMARY}

I. Albino and piebald rats were kept on diets deficient in vitamin A or vitamin E, or with supplements of these vitamins, in order to study the effect on the state of their maxillary incisor teeth. The teeth were examined by observing their colour and by analysing the enamel and dentin for iron and manganese by flame spectrophotometry.

2. The diminution of iron in the depigmented enamel of the incisor teeth of rats deficient in vitamin $\mathrm{E}$ was confirmed. Thus the ash of the enamel from deficient animals contained $<0.02-0.039 \%$, compared with $0.071-0.27 \%$ in rats dosed with vitamin $\mathrm{E}$. The amounts of iron in the dentin from deficient or dosed animals, were usually too low for analysis.

3. The same fall in the iron content of the enamel was observed in teeth that had been bleached by deficiency of vitamin A.

4. The quantities of manganese in all the specimens of ash were too low for estimation.

5. Piebald rats were more resistant than albinos to dental depigmentation during vitamin $\mathrm{E}$ deficiency, but depigmentation occurred readily in both strains during vitamin A deficiency.

6. Alterations in the degree of pigmentation were not seen on the exposed part of the teeth until several weeks after the corresponding dietary change. The delay was presumably caused by the lapse of time before the emergence of that part of the tooth being formed when the dietary change was made.

Our thanks are due to Dr L. J. Harris for his valuable criticism, and to Mrs A. C. Bright and Miss M. Tearle for technical assistance. The spectro-chemical analyses were carried out by Mrs I. M. Johnston and Miss D. M. Keith at the Macaulay Institute for Soil Research, Aberdeen.

\section{REFERENCES}

Bacharach, A. L., Cuthbertson, W. F. J. \& Thornton, D. M. (1949). Brit. F. Nutr. 3, 3.

Dam, H. \& Granados, H. (1945). Science, 102, 327.

Dam, H., Granados, H. \& Maitesen, L. (1950). Acta physiol. scand. 21, 124.

Duckworth, J. (I942). Private communication.

Farmer, V. C. (1950). Spectrochim. Acta, 4, 224.

Fish, E. W. \& Harris, L. J. (1934). Phil Trans. B, 223, 489.

Irving, J. T. \& Richards, M. B. (1939). Nature, Lond., 144, 908.

Lowater, F. \& Murray, M. M. (I937). Biochem. F. 31, 837 .

McCollum, E. V., Simmonds, N., Becker, J. E. \& Bunting, R. W. (1925). F. biol. Chem. 63, 553.

Mellanby, H. (1939). Brit. dent. $\mathscr{7} .67$, r87.

Moore, T. (1943). Biochem. $\mathcal{F} .37,112$.

Moore, T. (1948-9). Brit. F. Nutr. 2, 407.

Moore, T. (1950). Brit. F. Nutr. 4, xviii.

Murray, M. M., Glock, G. E. \& Lowater, F. (1939). Brit. dent. F. 66, 345.

Schour, I., Hoffman, M. M. \& Smith, M. C. (194I). Amer. F. Path. 17, 529.

Schour, I., Smith, M. C. \& Hoffman, M. M. (1938). Proc. Soc. exp. Biol., N.Y., 39, 447.

Smith, M. C. \& Lantz, E. M. (1933). F. Home Econ. 25, 4 I I.

Telford, I. R. (1946). Proc. Soc. exp. Biol., N.Y., 63, 89 .

Wolbach, S. B. \& Howe, P. R. (1925). F. exp. Med. 42, 753.

Wolbach, S. B. \& Howe, P. R. (1933). Amer. F. Path. 9, 275. 